\title{
Antiepileptic Drug Selection and Adverse Effects: An Overview
}

\author{
J. Bruni
}

\begin{abstract}
In choosing an antiepileptic drug, not only efficacy but also potential adverse effects have to be considered. Adverse effects that have to be taken into account include acute and chronic systemic toxicity, cognitive side effects, and teratogenesis. Acute toxicity may be dose-related, allergic or an idiosyncratic reaction. Chronic toxicity may involve the nervous system or other organs. In determining the role of new antiepileptic drugs such as lamotrigine, vigabatrin, felbamate, and gabapentin a proper evaluation of both efficacy and adverse effects is required.
\end{abstract}

\begin{abstract}
Résumé: Choix d'une médication anti-epileptique et effets secondaires. Lors du choix d'une médication antiépileptique, on doit considérer non seulement son efficacité, mais aussi ses effets secondaires possibles. Parmi ceux-ci, on doit tenir compte de la toxicité systémique aiguë et chronique, des effets secondaires congnitifs et du potentiel tératogène. La toxicité aiguë peut être une réaction reliée à la dose, à l'allergie ou à l'idiosyncrasie. La toxicité chronique peut impliquer le système nerveux ou d'autres organes. Une évaluation appropriée de l'efficacité et des effets secondaires est nécessaire pour déterminer le rôle des nouveaux médicaments anti-épileptiques tels la lamotrigine, la vigabatrine, le felbamate et la gabapentine.
\end{abstract}

Can. J. Neurol. Sci. 1994; 21: Suppl. 3-S3-S6

In choosing an antiepileptic drug, a number of factors have to be taken into consideration: efficacy of the drug against a specific seizure type and epilepsy syndrome, pharmacokinetics of the drug, age and sex of the patient, potential adverse effects, teratogenic effects, emergency use and cost.

There are a number of recent efficacy studies in the treatment of epilepsy. ${ }^{1-9}$ Data from the Veterans Administration (VA) Cooperative Study ${ }^{5}$ demonstrated that in the treatment of partial seizures, there was little difference in the efficacy of phenytoin, carbamazepine, primidone and phenobarbital. However, when these patients were followed for 3 years, more patients discontinued primidone and phenobarbital than the other two drugs because of adverse effects. This result was also true in the treatment of generalized tonic-clonic seizures. Primidone fared less well in terms of successful therapy, and most of the patients that had to discontinue it did so because of adverse effects, not because of inadequate seizure control alone.

Valproate has been found to be less effective than carbamazepine in the treatment of partial seizures but both are equally effective against secondarily generalized tonic-clonic seizures. ${ }^{9}$

In the treatment of primary generalized epilepsy valproate has broad spectrum activity against tonic-clonic, typical and atypical absence and myoclonic seizures. It is equally effective as ethosuximide in the treatment of typical absences and may be superior to ethosuximide in the treatment of atypical absences.

The initiation of antiepileptic drug therapy should consist of using the most appropriate drug as monotherapy to reduce the incidence of adverse effects and eliminate drug interactions.
Polytherapy with two drugs and, rarely, three drugs may improve seizure control in a small number of patients. Patients that may benefit from "rational" polytherapy may include patients with multiple seizure types, patients with refractory epilepsy syndromes such as the Lennox-Gastaut syndrome, patients with progressive neurologic disease or post-traumatic seizures. When used in combination drugs with sedative or cognitive side effects should be avoided and drugs with different mechanisms of action are preferred. Table 1 is a summary of the efficacy of the antiepileptic drugs.

\section{Adverse Effects of Drugs}

It is apparent that adverse effects of the major antiepileptic drugs are important considerations in drug selection. One can think of antiepileptic drug side effects in several major categories. The acute side effects are usually allergic, dose related, or idiosyncratic in nature. Because patients with epilepsy are treated over long periods of time, we have to be concerned about possible chronic side effects. We also have to be concerned about adverse effects secondary to drug interactions and potential teratogenic effects (Table 2).

Data from the Collaborative Group for Epidemiology of Epilepsy Study ${ }^{10}$ show that adverse effects may be seen in up to

From the University of Toronto and Division of Neurology, The Wellesley Hospital, Toronto.

Reprint requests to: Dr. J. Bruni, The Wellesley Hospital, Room 318, Jones Building, 160 Wellesley Street East, Toronto, Ontario, Canada M4Y 1J3 
Table 1. Efficacy of Antiepileptic Drugs.

\begin{tabular}{|c|c|c|c|c|}
\hline Seizure Type & Drugs of Choice & Alternate Drugs & "Rational" Polytherapy & Investigational Drugs \\
\hline \multicolumn{5}{|l|}{ Generalized } \\
\hline Tonic-clonic & Valproate & $\begin{array}{l}\text { *Phenytoin } \\
{ }^{*} \text { Carbamazepine } \\
\text { Phenobarbital } \\
\text { Primidone } \\
\text { Clobazam }\end{array}$ & $\begin{array}{l}\text { *Valproate + Phenytoin } \\
* \text { Valproate + Carbamazepine }\end{array}$ & Lamotrigine \\
\hline Absence & $\begin{array}{l}\text { Ethosuximide } \\
\text { Valproate }\end{array}$ & $\begin{array}{l}\text { *Clobazam } \\
\text { Acetazolamide }\end{array}$ & $\begin{array}{l}\text { *Ethosuximide + Valproate } \\
\text { Ethosuximide + Clobazam } \\
\text { Valproate + Clobazam } \\
\text { Valproate + Acetazolamide } \\
\text { Ethosuximide + Acetazolamide }\end{array}$ & Lamotrigine \\
\hline \multicolumn{5}{|c|}{ Secondarily generalized tonic-clonic } \\
\hline & $\begin{array}{l}\text { Phenytoin } \\
\text { Carbamazepine }\end{array}$ & $\begin{array}{l}\text { *Valproate } \\
\text { Vigabatrin } \\
\text { Primidone } \\
\text { Clobazam }\end{array}$ & $\begin{array}{l}* \text { Phenytoin + Valproate } \\
* \text { Carbamazepine + Valproate } \\
\text { Carbamazepine + Vigabatrin } \\
\text { Phenytoin + Vigabatrin }\end{array}$ & $\begin{array}{l}\text { Gabapentin } \\
\text { Lamotrigine }\end{array}$ \\
\hline
\end{tabular}

* First Alternative

Table 2. Antiepileptic Drug Toxicity.

1. Acute

$$
\begin{aligned}
& \text { - Dose related } \\
& \text { - Allergic } \\
& \text { - Idiosyncratic }
\end{aligned}
$$

2. Chronic

3. Secondary to drug interactions

$$
\begin{aligned}
& \text { - Pharmacodynamic } \\
& \text { - Pharmacokinetic }
\end{aligned}
$$

4. Teratogenic Effects

one-third of patients. The greater the number of drugs the patient is on, the greater the incidence of adverse effects. Patients with severe epilepsy who are taking two or three drugs have an incidence of adverse effects in the range of $30-40 \%$.

\section{Acute Effects}

Acute dose-related adverse effects usually occur early in the course of therapy or when the antiepileptic drug dose is increased. Acute dose-related side effects generally involve central nervous system function or gastrointestinal side effects.

With most of the antiepileptic drugs, allergic skin rashes can occur in $5-10 \%$ of patients. In most cases, these are mild, but occasionally they may require discontinuation of therapy. ${ }^{11}$

Idiosyncratic drug reactions are rare but potentially serious. They are not dependent on dose and usually occur early in therapy. Many of these are skin reactions, for example, exfoliative dermatitis, Stevens-Johnson syndrome, and Lyell's syndrome. Antiepileptic drug idiosyncratic reactions have been described with all the currently available major drugs but are most common with phenytoin, phenobarbital and carbamazepine.

Pancreatitis is an idiosyncratic reaction that has been described with carbamazepine and valproate. ${ }^{12-17}$ This reaction is more common in children than in adults.

Hepatic adverse effects of antiepileptic drugs range from common, mild, transient elevations of hepatic enzymes without clinical symptoms to uncommon, fatal hepatotoxicity. Fatal hepatotoxicity may occur as an idiosyncratic reaction or from aberrant metabolism resulting in hepatotoxic metabolites. Hepatotoxicity can occur with most of the antiepileptic drugs. Although the use of valproate has increased since its introduction in North America in 1978, the number of fatal toxic reactions associated with its use has declined. A high risk group has been identified: children under 2 years of age who are on 
polytherapy and who have a neurologic handicap. Dreifuss and others have contributed significantly to our understanding of valproate hepatoxocity. ${ }^{18-21}$

Antiepileptic drug interaction with hepatic enzyme inhibitors may result in acute toxicity. Erythromycin, cimetidine, isoniazid, disulfiram, calcium-channel blockers and some antidepressants may cause elevated antiepileptic drug levels when used concurrently. $22-26$

\section{Chronic Effects}

Chronic toxicity may be seen with most of the antiepileptic drugs. Factors that influence the development of chronic toxicity are age of onset of epilepsy, age of the patient, duration of therapy, polytherapy, nutritional status, genetic factors and, most importantly, the physician's awareness of the potential dangers of chronic drug therapy. Antiepileptic drugs affect all systems, but certain structures appear to be more vulnerable than others. With long term therapy, we have to keep in mind the effect of medications on the skin, connective tissues, nervous system, skeletal system, endocrine system, and hematopoietic system. ${ }^{27}$

Many studies have confirmed that gingival hyperplasia may be seen in a small number of patients treated with phenytoin. Certain risk factors have been identified: age less than 30 years old, poor oral hygiene, residence in an institution, and perhaps some genetic susceptibility. ${ }^{28-31}$

Cognitive side effects are important considerations when using antiepileptic drugs. The barbiturates appear to have the greatest incidence of cognitive adverse effects; phenytoin and carbamazepine have an equal incidence, and valproate has the lowest incidence. ${ }^{32-41}$

\section{Teratogenic Effects}

The final aspect of antiepileptic drug adverse effects that has to be considered is the teratogenic potential of the currently available medications. ${ }^{42-50}$ Generally there is a two or three fold increase in the incidence of minor anomalies and malformations in the offspring of mothers with epilepsy; however, one has to separate what is related to drug effect and what is related to genetic predisposition.

Neural tube defects are of some concern with the use of valproate and carbamazepine. ${ }^{46,48,51-54}$ It is generally felt that there is a 1 or 2 percent risk of neural tube defects if the fetus is exposed to valproate in the first trimester of pregnancy, and perhaps there is also a slight increase in risk in children exposed to carbamazepine.

\section{New Drugs}

With the expected introduction in the near future of currently investigational drugs such as gabapentin, lamotrigine, vigabatrin and felbamate, not only their efficacy but also their adverse effects will have to be placed in proper perspective. It is hoped that these agents will improve the quality of life of patients with epilepsy without excessive undesirable effects. ${ }^{55-65}$

The following symposium will address in greater detail the more important aspects of the adverse effects of antiepileptic drugs.

\section{REFERENCES}

1. Covanis A, Gupta AK, Jeavens PM. Sodium valproate: monotherapy and polytherapy. Epilepsia 1982; 23: 693-700.

2. Wilder BJ, Ramsay RE, Murphy JV, et al. Comparison of valproic acid and phenytoin in newly diagnosed tonic-clonic seizure. Neurology 1983; 33: 1474-1476.
3. Callaghan N, Kenny RA, O'Neill B, et al. A prospective study between carbamazepine, phenytoin and sodium valproate as monotherapy in previously untreated adult epileptic patients. J Neurol Neurosurg Psychiatry 1985, 48: 639-644.

4. Turnbull DM, Howell D, Rawlins MD, et al. Which drug for the adult epileptic patient: phenytoin or valproate? Br Med J 1985; 290: 815-819.

5. Mattson RH, Cramer JA, Collins JF, et al. Comparison of carbamazepine, phenobarbital, phenytoin and primidone in partial and secondarily generalized tonic-clonic seizures. N Engl J Med 1985; 313: 145-151.

6. Bourgeois B, Beaumanoir A, Blajev B, et al. Monotherapy with valproate in primary generalized epilepsies. Epilepsia 1987; 28 (Suppl 2): S8-S11.

7. Chadwick DW. Valproate monotherapy in the management of generalized and partial seizures. Epilepsia 1987; 28 (Suppl 2): S12S17.

8. Dean JC, Penry JK. Valproate monotherapy in 30 patients with partial seizures. Epilepsia 1988; 29: 140-144.

9. Mattson RH, Cramer JA, Collins JF, et al. A comparison of valproate with carbamazepine for the treatment of complex partial seizures and secondarily generalized tonic-clonic seizures in adults. N Engl J Med 1992; 327: 765-769.

10. Collaborative Group for Epidemiology of Epilepsy. Adverse reactions to antiepileptic drugs: a multicentre survey of clinical practice. Epilepsia 1986; 27: 323-330.

11. Chang DKM, Shear NH. Cutaneous reactions to anticonvulsants. Seminar Neurol 1992; 12: 329-337.

12. Soman M, Swenson C. A possible case of carbamazepine-induced pancreatitis. Drug Intell Clin Pharm 1985; 19: 925-927.

13. Camfield PR. Pancreatitis due to valproic acid. Lancet 1979; 1: 1198-1199.

14. Parker PH, Helinek GH, et al. Recurrent pancreatitis induced by valproic acid. Gastroenterology 1981, 80: 825-828.

15. Williams LH, Reynolds RP, Emery JL. Pancreatitis during sodium valproate treatment. Arch Dis Child 1983; 58: 543-544.

16. Wyllie E, Wyllie R, Cruse RP, et al. Pancreatitis associated with valproic acid therapy. Am J Dis Child 1984; 138: 912-914.

17. Asconape JJ, Penry JK, Dreifuss FE, et al. Valproate associated pancreatitis. Epilepsia 1993; 34: 177-183.

18. Zimmerman H, Ishak $K$. Valproate-induced hepatic injury: analyses of 23 fatal cases. Hepatology 1982; 2: $591-597$.

19. Powell-Jackson PR, Tredger JM, Williams R. Hepatotoxicity to sodium valproate. A review. Gut 1984; 25: 673-681.

20. Dreifuss FE, Santilli N, Langer DH, et al. Valproic acid hepatic fatalities: a retrospective study. Neurology 1987; 37: 379-385.

21. Dreifuss FE, Langer DH, Moline KA, et al. Valproic acid hepatic fatalities II. U.S. experience since 1984. Neurology 1989; 39 : 201-207.

22. Albright PS, Bruni J. Pharmacokinetic interactions of antiepileptic drugs. Can J Neurol Sci 1984; 11: 247-251.

23. Brodie MJ. Drug interactions in epilepsy. Epilepsia 1992; 33 (Suppl 1): S13-S22.

24. Bahls F, Ozuna J, Ritchie DE. Interactions between calcium channel blockers and the anticonvulsants carbamazepine and phenytoin. Neurology 1991; 41: 740-742.

25. Pitlick WH. Antiepileptic Drug Interactions. Demos Publications. New York, 1989.

26. Bruni J. Epilepsy in adolescents and adults. Conn's current therapy. Rakel R.E., ed. Toronto: W.B. Saunders, 1993: 851-860.

27. Bruni J, Wilder BJ. Toxicology of antiepileptic drugs. In: Vinken and Bruyn, eds. Handbook of Clinical Neurology. Intoxications of the Nervous System, Vol 37, Pt 2. Amsterdam: North Holland Publishing Company, 1979: 199-222.

28. Klar LA. Gingival hyperplasia during Dilantin therapy: a survey of 312 patients. J Publ Health Dent 1973; 33: 180-185.

29. Dahllof $G$, Modeer $T$. The affect of a plaque control program on the development of phenytoin-induced gingival overgrowth: a 2 year longitudinal study. J Clin Periodontol 1986; 13: 845-849.

30. Hall WB: Dilantin hyperplasia: a preventable lesion. J Periodontol Res 1969; 4 (Suppl): 36-37. 
31. Phenytoin-Induced Teratology and Gingival Pathology. Hassel T.M., Johnston M.C., Dudley K., eds. New York: Raven Press, 1980.

32. Trimble MR. Anticonvulsant drugs and cognitive function: a review of the literature. Epilepsia 1987; 28 (Suppl 3): 537-545.

33. Vining EPG, Mellitis ED, Dorsen MM, et al. Psychologic and behavioural effects of antiepileptic drugs in children: a double blind comparison between phenobarbital and valproic acid. Pediatrics 1987; 80: 165-174.

34. Reynolds EH, Trimble MR. Adverse neuropsychiatric effects of anticonvulsant drugs. Drugs 1985; 29: 570-581.

35. Dodrill CB. Diphenylhydantoin serum levels, toxicity and neuropsychological performance in patients with epilepsy. Epilepsia 1975; 16: 593-600.

36. Thompson PJ, Trimble MR. The effect of anticonvulsant drugs on cognitive function: relation to serum levels. J Neurol Neurosurg Psychiatry 1983; 46: 227-233.

37. Meador KJ, Loring DW, Huh K, et al. Comparative cognitive effects of anticonvulsants. Neurology 1990; 40: 391-394

38. Meador KJ, Loring DW, Allen ME, et al. Comparative cognitive effects of carbamazepine and phenytoin in health adults. Neurology 1991; 41: 1537-1540.

39. Trimble MR. Neurobehavioural effects of anticonvulsants. JAMA 1991; 265: 1307-1308.

40. Smith DB, Mattson RH, Cramer JA, et al. Results of a nationwide Veteran Administration Cooperative Study comparing the efficacy and toxicity of carbamazepine, phenobarbital, phenytoin and primidone. Epilepsia 1987; 28 (Suppl): S50-S58.

41. Dodrill CB, Troupin AS. Neuropsychological effects of carbamazepine and phenytoin: a reappraisal. Neurology 1991; 41: 141-143.

42. Kaneko S, Otani K, Kondo T, et al. Malformation in infants of mothers with epilepsy receiving antiepileptic drugs. Neurology 1992; 42 (Suppl 5): 68-74

43. Dravet C, Julian C, Legras C, et al. Epilepsy, antiepileptic drugs and malformations in children of women with epilepsy. Neurology 1992; 42 (Suppl 5): 75, 82.

44. Koch S, Losche G, Jager-Roman E, et al. Major and minor birth malformations and antiepileptic drugs. Neurology 1992; 42 (Suppl 5): 83-88.

45. Tanganelli P, Regesta G. Epilepsy, pregnancy and major birth anomalies: an Italian prospective, controlled study. Neurology 1992; 42 (Suppl 5): 89-93.

46. Lindhout D, Omtzigt JGC, Cornel MC. Spectrum of neural tube defects in 34 infants prenatally exposed to antiepileptic drugs. Neurology 1992; 42 (Suppl 5): 111-118.

47. Gaily E, Granstrom M-L, Hiilesmaa V, et al. Minor anomalites in offspring of epileptic mothers. J Pediatr 1988; 112: 520-529.
48. Rosa FW. Spina bifida in infants of women treated with carbamazepine during pregnancy. N Engl J Med 1991; 324: 674-677.

49. Dansky LV, Andermann E, Anderman F, et al. Maternal epilepsy and congenital malformations: correlation with maternal plasma anticonvulsant levels during pregnancy. In: Janz D, Dam M, Richens A, et al., eds. Epilepsy, Pregnancy and the Child. New York: Raven Press, 1982: 251-258.

50. Jones KL, Lacro RV, Johnson KA, et al. Pattern of malformations in the children of women treated with carbamazepine during pregnancy. N Engl J Med 1989; 320: 1661-1666. 1982: 251-258.

51. Robert E, Rosa FW. Maternal valproic acid and congenital neural tube defects. Lancet 1982; 2: 937.

52. Lindhout D, Schmidt D. In-utero exposure to valproate and neural tube defects. Lancet 1986; 2: 1392-1393.

53. Valproate, spina bifida and birth defects registries (editorial). Lancet 1988; 2: 1404-1405.

54. Omtzig JG, Los FJ, Grobbee DE, et al. The risk of spina bifida after first-trimester exposure to valproate in a prenatal cohort. Neurology 1992; 42 (Suppl 5): 119-125.

55. Ramsay RE. Advances in the pharmacotherapy of epilepsy. Epilepsia 1993; 34 (Suppl 5): S9-S16.

56. Sachdeo R, Kramer LD, Rosenberg A, et al. Felbamate monotherapy: controlled trial in patients with partial onset seizures. Ann Neurol 1992; 32: 386-392.

57. The Felbamate Study Group in Lennox-Gastaut Syndrome. Efficacy of felbamate in childhood epileptic encephalopathy (Lennox-Gastaut Syndrome). N Engl J Med 1993; 328: 29-33.

58. Schapel GJ, Beran RG, Vajda FJE, et al. Double-blind, placebo controlled, cross-over study of lamotrigine in treatment of resistant partial seizures. Epilepsia 1991: 32 (Suppl): 58.

59. Risner ME. Lamictal Study Group. Multicentre, double-blind, placebo-controlled, add-on, cross-over study of lamotrigine (Lamictal) in epileptic patients with partial seizures. Epilepsia 1990; 31: 619-620.

60. Crawford P, Ghadiali E, Lane R, et al. Gabapentin as an antiepileptic drug in man. J Neurol Neurosurg Psychiatry 1987; 50: 682686.

61. UK Gabapentin Study Group. Gabapentin in partial epilepsy. Lancet 1990; 335: 1114-1117.

62. Sivenius J, Kalviainen R, Ylinen A, et al. Double-blind study of gabapentin in the treatment of partial seizures. Epilepsia 1991; 34: 539-542.

63. Reynolds EH, Ring HA, Farr IN, et al. Open double-blind and long term study of vigabatrin in chronic epilepsy. Epilepsia 1991; 32: 530-538

64. Sivenius J, Ylinen A, Murros K, et al. Vigabatrin in drug-resistant partial epilepsy. Neurology 1991; 41: 562-565.

65. Browne TR, Mattson RH, Penry JK, et al. Multicentre long-term safety and efficacy study of vigabatrin for refractory complex partial seizures. Neurology 1991; 41: 363-364. 